\title{
Socio-Cultural Structure and Space that Transformed under the Influence of Population Movements (Migration) in Bursa
}

\author{
Fatma Busra Guler, Tulin Vural Arslan, and Selen Durak
}

\begin{abstract}
Migration is a significant phenomenon which shaped cities' social, economical and spatial characteristics throughout the history. Bursa has been a city which experienced many migration flows from its conquest by Ottomans in $14^{\text {th }}$ century till today. The population development of the city was based on immigrants from Balkan countries. Especially Turkish immigrants coming from Bulgaria preferred to settle in Bursa because of its similar characteristics with Bulgarian cities in terms of topography, climate and flora. Urban environment in Bursa has shaped by the cultural values of immigrants that were transferred throughout the history. The aim of this study is to discuss how the immigrants shape the spatial characteristic of Bursa and how their cultural values affect the formation of their housing environments in Bursa.
\end{abstract}

Index Terms-Migration, urban planning, housing, bursa.

\section{INTRODUCTION}

Hartshorne indicated that city is a very complex mechanism in which people or society have accumulated as regards to employment and lifestyles, where land use is dense, specialized with its various socio-economic and politic organizations and where the use of urban resources is regulated. Harvey, on the other hand, regarded the city as a form with a series of constructed structure and a whole related with everything in its operation [1]. Individuals shape and give the meaning to the environment they live in with their own cultural values. In parallel to this approach, Weber has justified that spatial aspect of the cities is defined by the social processes [2].

According to Wirth, city is a place not only where population and workplaces increase but one that gathers and transforms many distant societies of the world in a circular or network shape, puts people and activities together, starts and controls the center of economic, politic and cultural life [3].

In this context, it is possible to see the traces of each and every culture in the places which were formed by a combination of various cultural values. This concept could be specifically traced in societies formed by immigrants [4].

Since its conquest, a constant population movement and migration phenomenon is on the agenda in Bursa, which could be regarded among the metropolitan cities of $21 \mathrm{st}$ century.

Manuscript received December 31, 2014; revised May 4, 2015

The authors are with the Uludag University, Faculty of Architecture, Gorukle, Bursa 16059, Turkey (e-mail: fatmabusraguler@gmail.com, tulinv@yahoo.com, selendurak@gmail.com).
Today immigrants constitute $90 \%$ of its population. Migration history, which could be dated back to the conquest of the city, is reflected in city with the planned settlement of the Turkic tribes in the region. Jalali Riots in 16th century, Ottoman-Russian War in 1877-78, Balkan War in 1912, Population Exchange in 1914, Balkan migrations, domestic and external migrations caused by industrialization process and forced migration from Bulgaria in 1989 are the breaking points of migration history of Bursa.

Within the scope of the present study, fundamental breakpoints in socio-cultural transformation of Bursa will be evaluated from the migration phenomenon aspect and the influence of Migrations from Bulgaria the effects of which are the most prominent in urban development of today's Bursa.

\section{Major Population Movements, Historical Process AND SPACE IN BURSA}

Until the conquest of Bursa by Ottomans in 1326, the city of Bursa was limited to only the Castle. It is presumed that city fabric within the walls of the castle changed after XI. century when Turks arrived this region. Because, the population of the city increased with the settlement of the people who deserted the surrounding villages and towns because of Turkish raids within the walls of the castle where they thought was safe [5].

After conquering Bursa, Sultan Orhan left the place within the walls of the Castle, the houses and bazaars as they were and started to expand the city outside the walls and to prepare space for the Turkic tribes coming from Anatolia. Thus he had cultural and economic structures built outside the walls.

The region where the structures built by the order of Orhan Bey are located determines the city center and this commercial center hasn't change at all through centuries. Thus, the city of Bursa expanded by way of neighborhoods established around the social complexes built in the city and it is possible to assume that the transportation axes that connect neighborhoods were formed as such in this urban fabric [5].

While Sultan Orhan had structure complexes built to the east of the Castle, Murad I who superseded Orhan had a structure complex built in Cekirge and led to the expansion of the city to the west. Sultan Bayezid, on the other hand, had a social complex built in the opposite direction and this has presented an important point with regards to urban fabric of the city. The social complexes built by the order of Mehmed I and Murad II are important structure complexes built by 
considering the development of the city [6].

On the other hand, immigrants from Anatolia and Turkistan who settled in Bursa were inhabited in separate neighborhoods in the city. A neighborhood was formed in the places where dervishes such as Abdal (Wandering Dervish) Mehmed, Abdal Musa and Abdal Murad who came to Bursa during the conquest inhabited. People coming from Konya Eregli settled in Seker Hoca Neighborhood, the ones from Sivas in Sivasiler Neighborhood, the ones from Karaman in Karaman Neighborhood, the ones from Iran and Azarbayjan in Acemler Neighborhood down from Reyhan, a part of Bozkus tribe settled in Nalbantoglu Neighborhood. The ones from Turkistan were serttled in Ozbekler Dervish Monastery which do not exist today in Pınarbasi, the ones from India in Hindiler Monastery in Pinarbasi [5].

\section{A. Socio-Cultural and Spatial under the Influence of} Modernization Process between $17^{\text {th }}$ and $20^{\text {th }}$ Century

When it comes to the $17^{\text {th }}$ century the world started to change and Bursa which is in interaction with the world was affected by these changes. In this period Bursa has lost its quality of being the focus of world trade. It is seen that physical changes took place in parallel with the changes in the world and issues of urbanism were on agenda in $18^{\text {th }}$ century [7].

According to Tekeli, population of Bursa was 64.000 with 12.800 houses in the year 1573 and after the migrations into the cities following Jalali Riots the population reached 70.000 within $17^{\text {th }}$ century.

Economic crisis in Mediterranean world in 17th and 18th centuries decreased demand for silk and the city tended to downsize. Due to the tendency to decrease in the population in parallel with the downsizing in city economy, the travelers of the period made comments in the way that the city became vacated [8].

In the cadastral map prepared by Suphi Bey in the year 1862 in order to determine the current situation of the city after Bursa earthquake, it is determined that the city population was between 70.000 to 80.000 and of this population 6000 were Rum (Greek), 11.000 were Armenian, 3000 were Jew and the rest were Muslim teams [9].

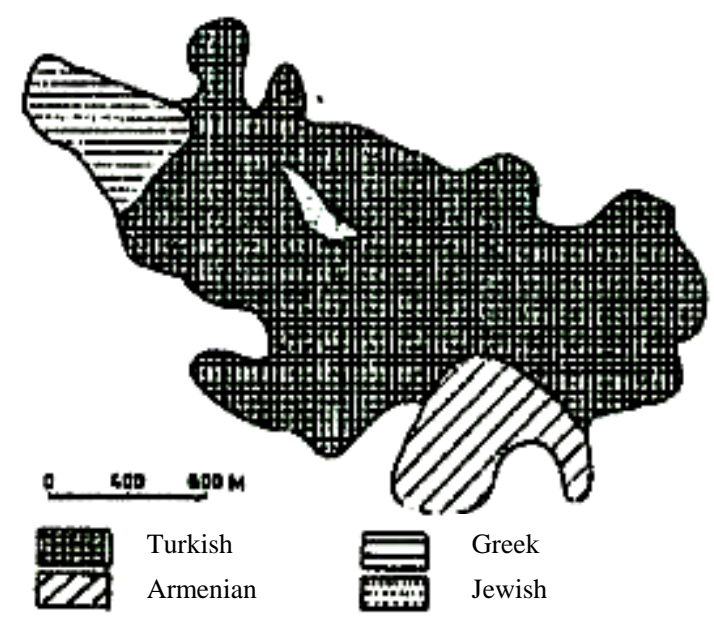

Fig. 1. Spatial distribution of the societies living in the city in 19th century [11].

After 1830 s, it was started to produce raw silk by using steam force and in 1860 two factories were established by the riverside of Cilimboz and Gokdere. It is known that mostly non-muslim women workforce worked in these factories [7]. This situation explains why non-muslim population gathered in the vicinity of the factory buildings Fig. 1.

Governor of the period Ahmet Vefik Pasa had Hocahasan, Intizam, Ruscuk and Cirpan Neighborhoods established for the immigrants who ran away from Rumelia, Romania and Bulgaria which were invaded at the end of 1877-78 Ottoman-Russian War to Istanbul and who were to be settled in Bursa within the frame of distribution into Anatolia [10]. These settlement plans were formed in grillage system that would support modern urbanization perception of the period and would enable rapid housing in Bursa with a settlement type that varied within urban fabric which could be called as organic.

The fact that entertainment venues and coffee houses were opened for the foreign merchant who came to the city during Vefik Pasa period is another spatial change. Consumption patterns brought by the orientation towards western culture caused shops that sold luxury consumer goods and coffee houses to be opened [10]. Bursa city center has expanded throughout the arteries around it without losing its form determined in $16^{\text {th }}$ century.

\section{B. Migration and City Since the Establishment of Turkish Republic (1923)}

The process of setting immigrants into the city which took place at the end of 1877-1878 Ottoman-Russian War has continued until today in various forms. The desire to settle in the areas where the acquaintances migrated before them settled which is the most important solidarity behavior of the immigrants has intensified this process [11].

According to J. McCarthy, 14.993 immigrants came from the Balkans between the years 1912-1915, however as there was the first World War immediately after it the settlement arrangements were postponed.

Population exchange that occurred between the years 1923-1926 is an important process that affected the city in Bursa. The rate of the non-muslims who consisted $25 \%$ of the city population in 1895 dropped to $3.2 \%$ in the population census in 1927. This situation caused a significant increase in general population and consequently a need arose for new housing zones and it entailed a capital planning study [11].

The immigrants who came from Balkans first and from Greece later with population exchange caused a cultural chaos in the first years of the Republic. The fact that the non-muslims who deserted Bursa were mostly craftsmen and merchants and their substitutes, the immigrants, were all farmers who had different culture and traditions and who didn't know the language even caused significant problems for Bursa in that period.

From the proclamation of the Republic till 1940s, new Turkish State has entered into a rapid reconstruction process after long-lasting wars. Within this context, specifically in 1930s important investments were made in tourism and industry sectors.

In 1925, the foundation for Ipek-Is Factory (Silk Factory) was laid by private entrepreneurs and it started to manufacture in 1930s. Within the frame of the First 
Industrialization Plan prepared in 1933, Merinos Wool Woven Weaving Factory and Gemlik Artificial Silk Factory were opened in Bursa in 1938. One other important development for city tourism was the fact that city center and thermal springs region of the city were connected by the opening of Celik Palas Hotel in 1938. After the formation of investment zones in the city many new facilities went into operation and private entrepreneurs were supported by the state. Such developments have been the factors that increased the industrialization of the city in the following year [8].

These investments and projections supported the development of Bursa from population aspect in parallel with the urbanization. Prepared development projections and entrepreneur incentives have caused intense industrialization movements in the city.

Spatial distribution of city population transformed with industrialization movements. Between the years 1945-1960 a population flow started both from the rural areas contingent upon the city and surrounding areas into Bursa which displayed a rapid development in its economic and industrial structure with its newly founded factories and industrial zones.

At the end of this change process that started in 1960s, the city doubled the population growth rate of the country in general as a result of the concentration in the labor demand. Under normal circumstances population increase in the city was calculated as increase in births; however, together with industrialization it continued based on the increase of the immigrant population in the city.

Together with industrialization, urban development balance of Bursa has developed as follows:

Bursa is one of the cities of Turkey with continuous and rapid population growth. The population increase of $6.38 \%$ between the years 1960-1965 has reached $6.4 \%$ after the year 1980.

The city of Bursa was established by the edge of a productive plain; therefore as a result of rapid population growth it was confronted with demands towards the plain.

On the face of all these increasing demands, various mechanisms of illegal supply of land increased and thus market for registered land with private shares has become quite active.

Due to the fact that Bursa has been one of the most important industrial cities of Turkey, the city has to push its historical and cultural city identity into the background [12].

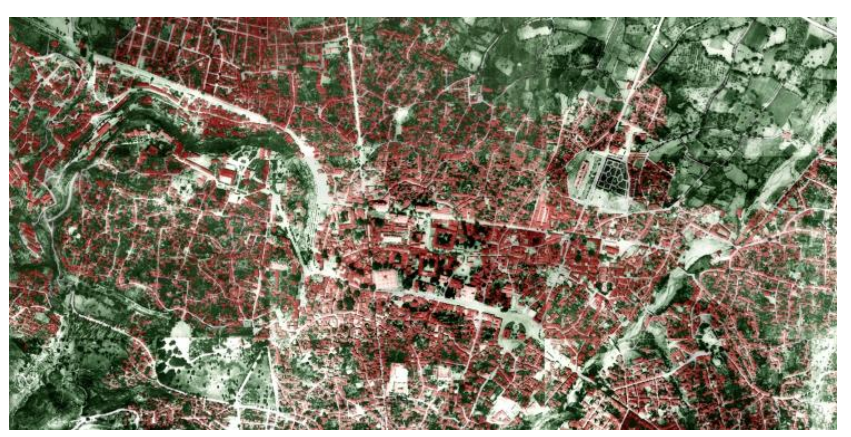

Fig. 2. Prost plan and bursa 1949 [11].

After World War II, it is possible to mention two events in the city of Bursa:

1) In 1940, as a result of the structural plan prepared by
Prost, it was decided to move the factories within the city to the north region of the city (see Fig. 2).

2) As a result of settling a major part of the Muslim Society of Turkish origin who were forced to migrate from Bulgaria between 1950-1951 in the city of Bursa, Hurriyet Neighborhood, on old Mudanya road and in the northwest of the city, was established as a new and dense residential area

These two important decisions have brought along significant developments for the city. Establishment of Hurriyet Neighborhood, moving the factories within the city to the north region and the fact that Merinos Laborer Houses were situated very close to Bursa plain all have accelerated the expansion towards north in the city scale.

The spread of housing areas towards north has started with the establishment of new neighborhoods for immigrants from Bulgaria who were settled in Bursa. Firstly Hurriyet Neighborhood was established on Mudanya road and then Istiklal, Adalet and Milliyet Neighborhoods were added to this settlement. In parallel with the development of Organized Industrial Zone on Mudanya road in 1966, laborer neighborhoods started to form in this area [8].

Spatial changes of the city reflect the self identity of the society that immigrated. The city of Bursa, which has a grand potential from economic aspect, has formed a unique culture mosaic with immigrant communities that inhabit in and form approximately $90 \%$ of the population of it.

\section{FORCED MigRATION FROM BULGARIA TO TURKEY}

In the years following the establishment of the Republic, the second major migration wave into Anatolia came from Bulgaria. Migrations from Bulgaria have continued at intervals and the most intense ones took place in 1950-1951 and 1989.

The final migration movement of immigrants from Bulgaria who constitute $48 \%$ of the total immigrants that came into the country in Republic period has started in the year 1989 when Muslim Bulgarian citizen of Turkish origin were forced to migrate into Turkey by Bulgarian government. In this period, 226.863 individuals belonging to 64.295 families have come to Turkey as free immigrants. From this date till 1995 the number of free immigrants coming at intervals has reached 73.957 belonging to 27.224 families [13], [14]. Thousands of immigrants coming from Bulgaria and Yugoslavia have also settled in Bursa.

Of the 25.583 families emigrating from Bulgaria into Turkey in 1950-1960 period, 2.185 farmer families and 1.356 craftsman families were settled in Bursa. The immigrants who came in 1989 from Bulgaria were united with their families and settled in the areas where their relatives and neighbors resided intensely. As a result of these and the people who come from other cities after 1970s the population of Bursa has increased rapidly [15] (see Table I).

In Bursa which is flooded by an intense immigrant flow particularly since 1980, the immigrants coming from Bulgaria are at the top of the list among the ones coming from abroad. The number of immigrants coming from Bulgaria is 133.056 [16].

For 1950-51 immigrants Hurriyet, Adalet and Istiklal 
Neighborhoods were selected as settlement areas (see Fig. 3). Apart from these neighborhoods, 1950-51 immigrants were settled in the west: Kiremitci, Carsamba Neighborhoods and in the area between Gazcilar Avenue and Santral Garaj, in the north: Gencosman, Papazcesme and south part of Kemercesme, north and south parts of old railroad, Uluyol neighborhood, Elmasbahceler, in the south: Ortayol, in the east: Sinandede, Davutkadi, Baruthane and Ortabaglar neighborhoods [17].

TABLE I: NET MigRATION AND NeT MigRATION RATE IN BURSA

\begin{tabular}{|c|c|c|c|c|c|}
\hline Year & Population & $\begin{array}{l}\text { Domestic } \\
\text { Migration } \\
\text { (Into) }\end{array}$ & $\begin{array}{l}\text { External } \\
\text { Migration } \\
\text { (Out of) } \\
\end{array}$ & $\begin{array}{l}\text { Net } \\
\text { Migration }\end{array}$ & \begin{tabular}{|l} 
Net \\
Migration \\
Rate $(\%)$ \\
\end{tabular} \\
\hline 1985 & 1.196 .255 & 94.085 & 46.651 & 47.434 & 40 \\
\hline 1990 & 1.399 .259 & 141.460 & 57.819 & 83.641 & 62 \\
\hline
\end{tabular}

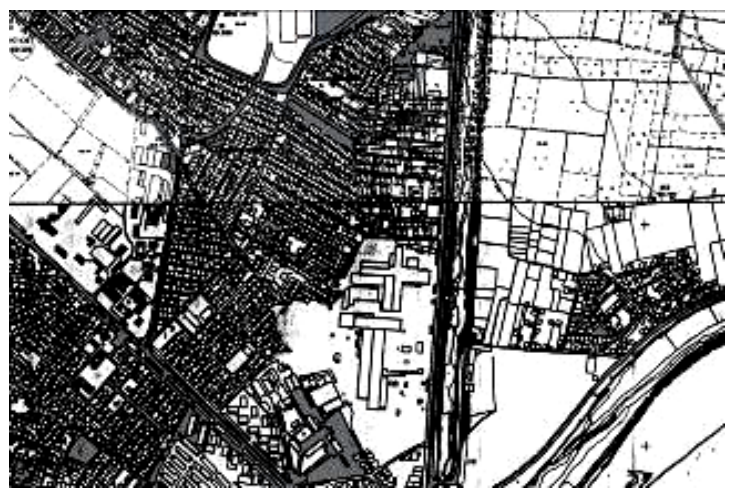

Fig. 3. 1997 map of Hurriyet, Istiklal and Adalet neighborhoods with a scale of $1 / 500$ [17].

In 1989, 1 out of every 4 immigrants who came with forced migration settled in Bursa. The number of immigrants settled in Bursa is 52.997. Mass housing projects were carried out in Kestel, Gorukle town of Nilufer District (see Fig. 4) and Yenice town of Inegol for immigrants (see Fig. 5).

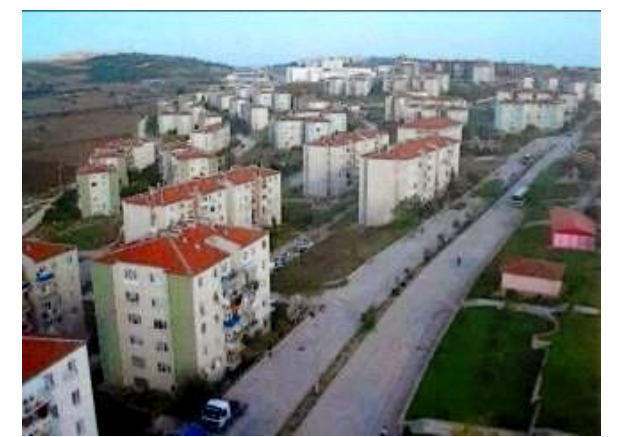

Fig. 4. A view from Gorukle immigrant houses [photo from Saban Ozturk's archive].

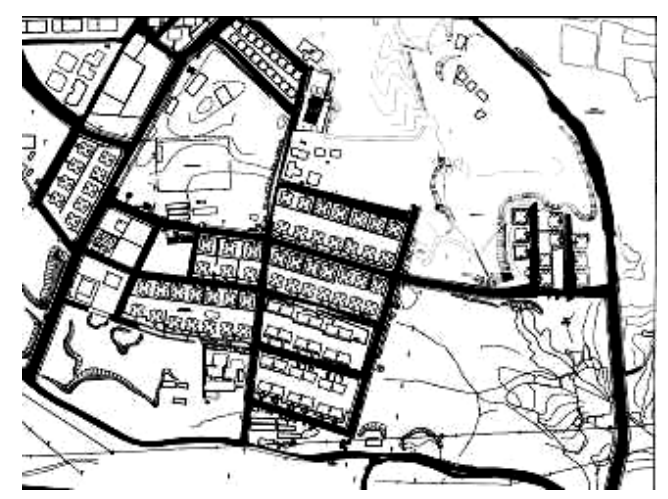

Fig. 5. $\overline{1997}$ Map of Kestel immigrant houses with a scale of 1/500 [17].
For 1989 immigrants, outside of settlement housing areas are in the south and west sections of the city [12]. It is indicated that share registered unlicensed constructions are usually to the north of Ankara road, in the south between Yildirim and Kestel, to the east and north of Bursa-Mudanya road, particularly around Emek municipality and around Hamitler.

When settlement areas in Bursa are examined, it is seen that there are many areas formed in Ankara Mudanya direction with intense immigrant population. This diversity undoubtedly changes the cultural texture and values of the city and creates variety in its social structure. Cultural diversity stands out in many stages from settlement formation infrastructure to the social lives of the communities. It is known that illegal housing has caused major problems in the city in general and that many settlement areas consist of such construction models.

When the qualities of settlement areas are examined, it is seen that a set of primary relations has created these formations. Settlement areas were developed by abiding the race, language, religion and fellow citizenship of the immigrants. These formations continuously add new inhabitants to themselves mostly by way of migrations.

\section{IMMIGRANTS FROM BULGARIA AND HOUSING}

Housing is one of the most important elements that reflect social, economic and spatial changes. Housing can be defined as "the structures which are constructed in cities or rural areas in a way that would provide ease of use and is appropriate for the life styles of people who are single, married, with one or more children, older, handicapped, special conditions (immigrants, natural disaster victims, etc.) and which provide shelter for individuals to be able to maintain their lives and are built after going through the phases of need, venture, project designing, construction and use".

As is indicated in the book by Sennett (1996) named "The Fall of Public Man", as the cities became packed with people, these individuals started to lose their functional relations with each other. Due to this intense influx of people, urban life has increasingly become decolorized and eventually public space disappears. As a result of private life notion arising with the fear of the unknown people moved away from the crowds and shut themselves up in safe spaces. Thus, "houses" of individuals became more and more important as they are the places where individuals preserved their privacy and escaped from the obscurity and crowdedness of the city [18].

Housing pattern in Bursa has in fact been a reflection of this diversity that the city bears. Within this scope, general housing structure of the city can be grouped under certain categories. Houses of the $19^{\text {th }}$ century are structures that match their intended purpose and external structure. After 1930s, developments in the west of the city accelerated and housing areas in the southwest has become a prestigious zone. Despite the inconvenient topography, multistory buildings were constructed in these areas. The housing structure in this area is in a style that is completely dissociated from the city. For the immigrants who were settled in Bursa in Republic period, on the other hand, one or more storey low standard single houses on single parcel of land were constructed in 
grillage system. In 1950s, work structure changed and a rapid apartment building process has started. Besides these, there are housing structures in the city which are built by various organizations for their own employees such as Merinos Laborer Houses, DSI Blocks etc. Moreover, there are mass housing structures built in certain groups in the southeast and west of the city. Intense immigration movements that occurred towards the city have caused for the emergence of the slum houses in which the groups with low income have lived and settlement areas in shared graduated parcels. Shared graduated houses constitute $40 \%$ of the total number of houses in the city. These areas take space in the west of the city, on Mudanya-Bursa-Ankara road and an extensive part in the east of the city; moreover, in the south of the city they form the border of settlement area as a thin strip of land [8]. House is the space which the immigrant interacts first in the city which has transformed under the influence of population movements (migrations).

Upon the examination of the distribution of the areas where Turks live in Bulgaria to the country in general, it is seen that the intensity is in the rural areas. Most of the Bulgarian immigrants in Bursa have come from the city of Kircaali, a rural area in the south of Bulgaria. It is noted that the return to their homeland rates of the immigrants coming from more developed areas of Bulgaria are quite high. It is seen that the immigrant have preferred to settle primarily in Yesilyayla neighborhood of Bursa. The reason for this preference is the fact that their close relatives have been living in that area (see Fig. 6).

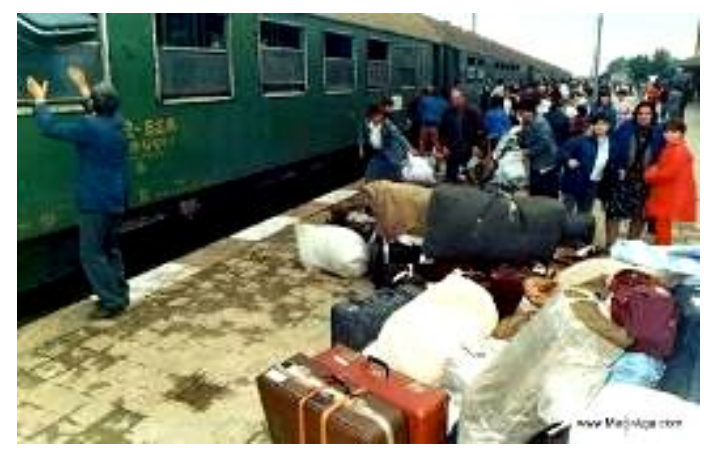

Fig. 6. Bulgarian immigrants, 1989 forced migration (Kapıkule) [19].

Bulgarian immigrants were also disappointed by the urban structure of the city. The immigrants have found houses for rent or built their own houses generally in the areas where illegal housing is intense and particularly the immigrants from rural areas had great difficulty in getting used to the neighborhoods with unplanned urbanization after living in multistory houses with gardens back in Bulgaria. Together with mass migration, housing need has become a major problem in Bursa and the government has formed mass housing areas in this direction.

\section{A. Qualities of Immigrant Houses}

Hurriyet, Adalet and Istiklal neighborhoods were selected as settlement areas for 1950-51 immigrants; however, we see that most of the buildings in those areas have been pulled down and transformed today [17].

The twin houses are approximately $40 \mathrm{~m}^{2}$ and are surrounded by a garden of $60 \mathrm{~m}^{2}$. The houses consist of two rooms and a living room and kitchen area [17]. In Hürriyet neighborhood in city center 324 houses and in Istiklal neighborhood 455 houses were built [19] (see Fig. 7).

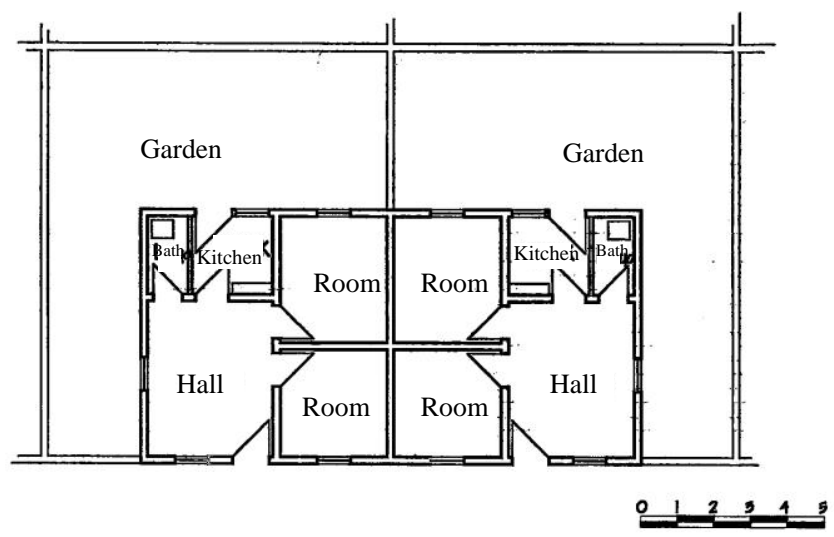

Fig. 7. Schematic plan of the houses built for 1950-51 immigrants in Bursa [17].
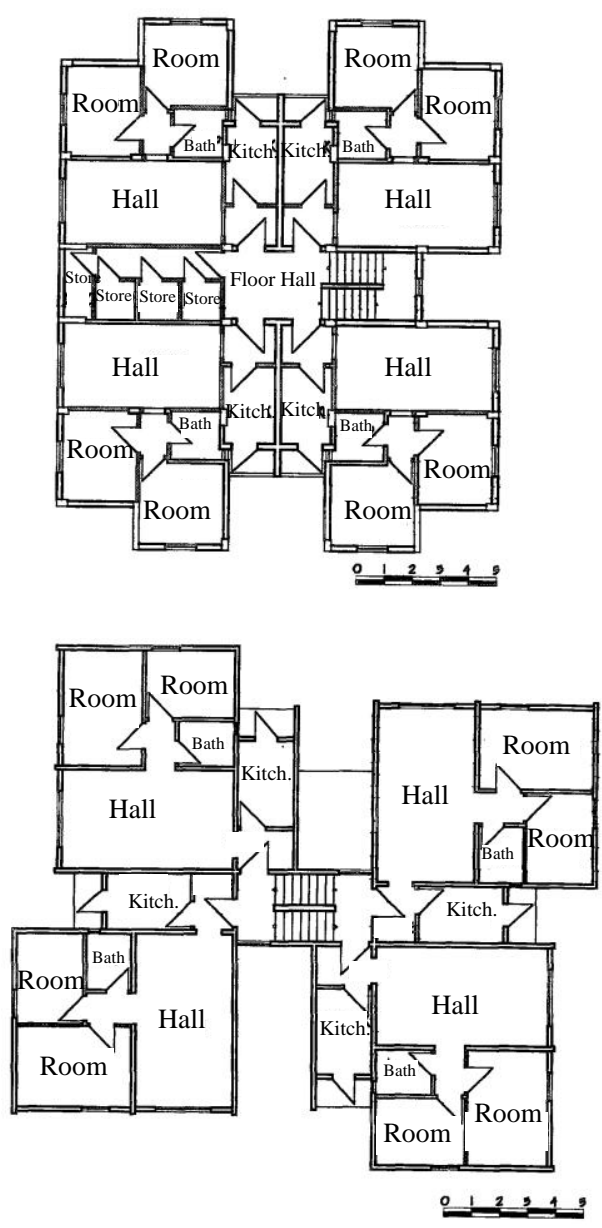

Fig. 8. Schematic plan of a few of the housing types constructed for immigrants of 1989 in Bursa [17].

Immigrant houses were built according to nuclear families as in size and spatial division. As a result of this situation the number of families $40 \%$ of which were living as nuclear family in Bulgaria are $66 \%$ in Turkey [17]. It could be said that physical space has caused for the definition of family concept to change primarily for immigrants.

It is seen that functional parts of the house (kitchen, bathroom and anteroom do not overlap with the spaces that 
have the same function in immigrants' minds. Contrary to the tendencies in Bulgaria, toilet has been moved inside. Kitchen falls short of satisfying its quality to be a place of production due to its small size. Anteroom exists in practice; however, it could not be used as the gathering place of the large families as it is in the definition in their minds.

It is noted that the immigrants use the gardens of the houses for agricultural purposes in accordance with their practices in Bulgaria and that they have organized the gardens in a way that they could rear small animals. Moreover, according to Oguz Arı's study in 1960, it is seen that immigrants have added toilet and coal cellar to their gardens as was their practice back in Bulgaria.

Today, almost none of these houses exist and they are replaced by 2-4 storey houses that inhabit large families or renewed apartment type houses.

For the settlement of Bulgarian immigrants of 1989, 1500 houses in Yenice village of Inegol town, 654 houses in Orhangazi town, 3000 houses Gorukle town and 2000 houses in Kestel town, a total of 7174 houses were built in Bursa (Archives of Public Works and Settlement Directorate of Bursa).

The houses in Gorukle and Kestel mass housing areas are 74-76 $\mathrm{m}^{2}$ and consist of two rooms, living room, kitchen, bathroom and anteroom. They also have two balconies, one of which is connected with the kitchen [17] (see Fig. 8).

The fact that the houses in which immigrants were settled were built for the purpose of meeting the minimum individual requirements has caused for the immigrants not to be able to meet some of their habits. Therefore, they have made some changes in the houses and expanded specifically the kitchen area with the aim of easing the storage and production functions in the kitchen (see Fig. 9).

Generally, the areas the immigrants were living back in Bulgaria were rural and lack of greenery in mass housing areas has been one of the major problems of the immigrants; therefore they have voluntarily worked in greening and landscaping of the gardens of the mass houses and the surrounding areas. Even today, immigrants living in mass houses are working voluntarily for the landscaping of the gardens, cleaning the common area of the mass houses. Additionally, they have been planting the herbs and plants that they have brought from their homeland and which could live in a similar climate (see Fig. 10).

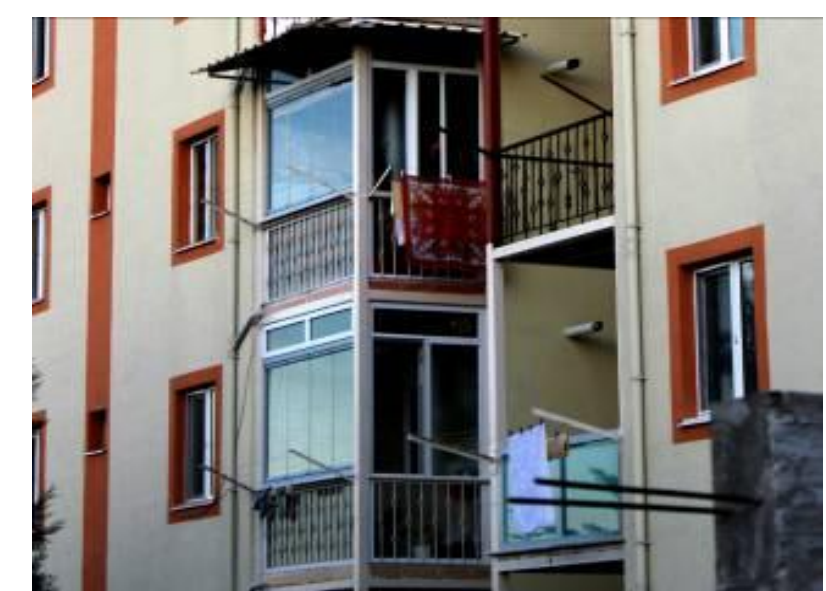

Fig. 9. A view of the recessed balconies in gorukle immigrant houses [photo from F. Busra Guler's archive].

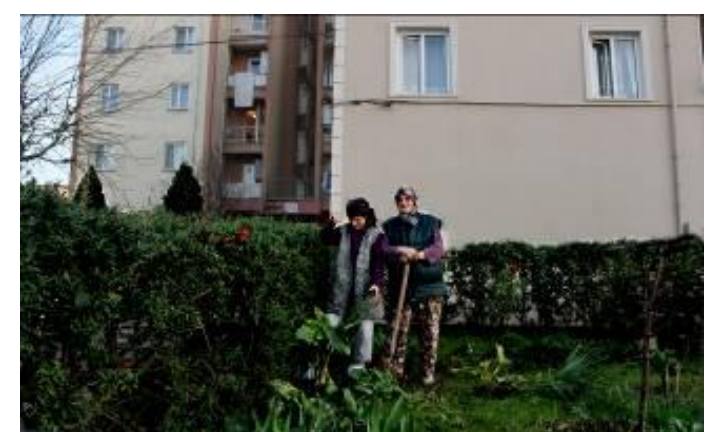

Fig. 10. Immigrants landscaping in gorukle immigrant houses [photo from F. Busra Guler's archive].

Garden is more like a follow-up of the private space rather than the reflection of a passage between private space and public space and the immigrants living in these mass housing areas have applied spatial practices they have established with the garden in Bulgaria into their new living environments. Particularly women and children spend time together in these gardens and use them for their social functions (see Fig. 11).

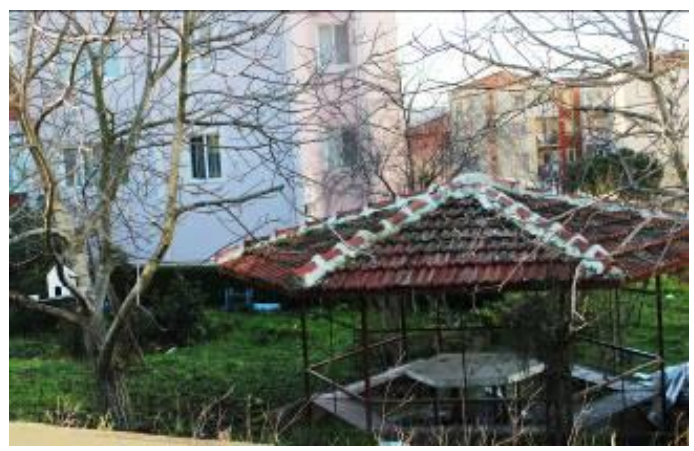

Fig. 11. Rest areas in the garden in gorukle immigrant houses [photo from F. Busra Guler's archive].

\section{CONCLUSION}

Population movements and settlement policies have an important place in the development of Bursa city structure since its conquest. There have been an excessive migration into the city above its infrastructure and capacity particularly after Ottoman-Russian War and this situation has put the city into a crisis. City has expanded in Mudanya Ankara direction with its population increasing incrementally with the effect of industrialization and domestic migration.

The city perception and housing expectation that changed together with globalization are directly related to these population movements specific to the city of Bursa. Need for housing that has increased together with growing population has formed new settlement areas. Illegal housing that was formed has become a major problem with the additional effect of inadequate infrastructure. Security problems increasing with cooperatives and migrations and ideal house myth of neo-liberal policies have triggered the transformation of the city.

Diversity and variety brought by the migrations undoubtedly enriches the cultural values of the city and creates variety in the social structure. Upon the examination of settlement areas, it is seen that race, religion, language, fellow citizenship of the immigrants are the determinant socio-cultural factors in the formation of these areas. While 
the city of Bursa transforms, it is constantly in interaction with this culture mosaic from the house use and space organization to the organization of a neighborhood and in a larger scale the organization of a city.

For the city of Bursa, the major mass migrations after World War II has been from Bulgaria and it is important to examine the relationship these immigrants have established with the space and their existing spatial practices in order to better understand the spatial crises of the city. The present study has examined the housing texture which Bulgarian immigrants mostly interact with in detail. While the immigrants have transformed physical space in direction of spatial practices, physical spaces have also changed the spatial practices of the immigrants. In accordance with the changing circumstances immigrants have adapted to the city with their transformed spatial practices. This study also aims to open the following topic into discussion: To what degree the user profile should be considered while the mass housing areas are formed? The fact that the user had to change the space or change their spatial practices in order to use their houses even in immigrant houses which have a very clear user profile during mass housing production process is an indication of the fact that the mass houses formed without adequate planning specific to Bursa are exposed to spatial crises.

\section{REFERENCES}

[1] D. Harvey, Social Justice and City, The Johns Hopkins University Press, Baltimore, p. 336, 1975.

[2] M. Weber, Sehir the City, Istanbul: Bakis Press, 2000, pp. 7-32

[3] L. Wirth, On Cities and Social Life: Selected Papers, Chicago: The University of Chicago Press, p. 350, 1964.

[4] K. Lynch, Kent Imgesi the Image of City, Istanbul: Is Bankasi Kultur Press, p. 291, 2010.

[5] R. Kaplanoglu, "Bursa'nin Kentsel Gelismesi (the urban development of Bursa)," Bursa Defteri Journal, issue 31, pp. 39-41, March 2008.

[6] F. Yenisehirlioglu, "XIV-XV Yuzyil Mimari Orneklere Gore Bursa Kentinin Sosyal, Ekonomik ve Kulturel Gelisimi (evaluating the social, economical and cultural development of Bursa in regarding to XIVth-XVth centuries' architectural examples)," in Proc. I $X^{\text {th }}$ Turkish History Congress, Ankara: Turkish History Foundation Press, 1989, vol. 3, pp.1345-1352.

[7] U. Tanyeli, 1900-2000 Konutu ve Modernlesmeyi Metropolden Okumak (Reading the Housing and Modernisation from the Metropolis), Istanbul: Ofset Publishing, p. 298, 2004.

[8] D. Mutman, "Bursa'da Gocmen Konutlarinin Olusumunda Kultur Mekan Etkilesimi (interaction of culture and space in the formation of migrant housing)," M.Arch Thesis, Department of Architecture, Uludag Univ., Bursa, Turkey, 2003.

[9] N. Dostoglu and E. Oral, "The physical transformation of the ottoman capital of Bursa from Tanzimat to republic," in 7 Centuries of Ottoman Architecture: A Supra-National Heritage, N. Akın, A. Batur, and S. Batur, Eds., Istanbul: YEM Publication, pp. 221-229, 1989.

[10] I. Tekeli, "Bursa'nin Tarihinde Uc Ayri Donusum Donemi (three transformation periods in the history $\mathrm{f}$ bursa)," in Proc. XI ${ }^{\text {th }}$ International Building and Life Congress, Bursa:Turkish Chamber of Architects' Bursa Branch Press, 1999, pp. 7-30.
[11] H. Turkoglu, "Cumhuriyet doneminde Bursa'nin kentsel gelisimi ve planlanmasi (the urban development and planning of bursa in the republican period)," Cumhuriyet Doneminde Bursa'da Kentlesme Sempozyumu (Urbanisation in Bursa in the Republican Period Symposium Proceedings Book), Bursa: Uludag University Press, 2011.

[12] O. Altaban, "Bursa Buyuksehir'de kentsel gelismenin bir bilancosu (an evaluation of urban development in bursa metropolitan city)," in Proc. $X I^{\text {th }}$ Building and Life Congress, Bursa: The Chamber of Architects Bursa Branch Press, 1999, pp. 169-193.

[13] S. Aytaç. (Summer 2004). Bursa'da Kültür Değișimi:Göç Olgusuna Sayısal Bir Bakış (The change of Culture in Bursa: An Quantative Approach to Migration). İş Güç Endüstri İlişkileri ve İnsan Kaynakları Journal [Online]. 6(2). pp. 10-20. Available: http://www.isgucdergi.org/?p=article $\& i d=212 \&$ cilt $=6 \&$ sayi $=2 \& y i l=2$ 004)

[14] DPT (Turkish Planning Organisation), Bulgaristan'dan Turk Gocleri, Uygulama Raporlari ve Notlari (The Reports and Notes about the Turks' Migration from Bulgaria to Turkey), Turkish State Planning Organization, Ankara, 1990

[15] Immigration by Provinces 2000 Country: Bursa, State and Statistics Institute. TC, Premiership. [Online]. Available: http://www.tuik.gov.tr/

[16] Public Cencus at 1990 Social and Economic Characteristics of the Population Statistics, State and Statistics Institute, TC, Premiership, DIE (State Staistical Institute) Press, Publication No: 1577, Ankara, 1993.

[17] B. Akgun, "Mekansal Imge- Mekansal Pratik İliski/İliskisizliginin Bursa'da 1950-1951 ve 1989 Bulgaristan Gocmenleri Uzerinde Incelenmesi (Spatial Image- the Evaluation of Spatial Practice Relationship on the 1950-51 and 1989 Bulgaria Migrants)," Ph.D Thesis, Dept. of Architecture, Gazi Univ., Ankara, Turkey 2001.

[18] R. Sennett, Kamusal Insanin Cokusu (the Fall of Public Man), Istanbul: Ayrinti Publishing, p.176, 1996.

[19] Photo archive. (1989). Immigration. [Online]. Available: http://www.maciraga.com/bulgaristan-zorunlu-goc-resimleri-1989

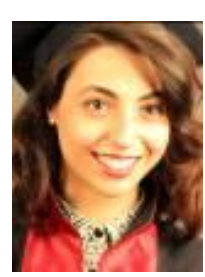

Fatma Busra Guler was born in Konya in 1991. She started architecture education in Erciyes University, and she was graduated as an architect from Erciyes University in 2014. She started to her master degree in Uludag University, Faculty of Architecture in 2014 and continues there. She worked with conversation works as an trainee architect in historical buildings in Turkey.

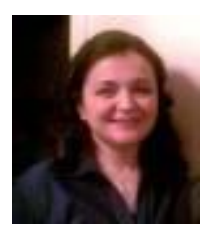

Tulin Vural Arslan was born in Bursa in 1974. She completed her bachelor degree of architecture in Middle East Technical University in 1996, and finished her master degree in Middle East Technical University, Faculty of Architecture in 1999 and PhD degree in Istanbul Technical University, Faculty of Architecture in 2005. Now she is working as an associate professor in Uludag University Faculty of Architecture.

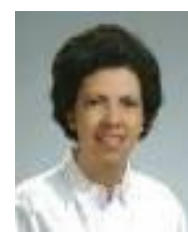

Selen Durak was born in Bursa in 1974. She completed her bachelor degree of architecture in Middle East Technical University in 1996, and finished master degree of architecture in Uludag University Architecture Department in 2003 and PhD degree in Middle East Technical University, Faculty of Architecture in 2010 Now she is working as an associate professor in Uludag University Faculty of Architecture. 